\title{
Anti-Inflammatory and Analgesic Activities of the Ethanolic Extract of the Leaf of Syzygium Guineense in Rats and Mice
}

\author{
${ }^{1}$ L. D. IOR, 1S. O. Otimenyin, ${ }^{2}$ M. Umar \\ IDepartment of Pharmacology, University of Jos, Jos, Nigeria \\ 2Department of Pharmacognosy, University of Jos, Nigeria
}

\begin{abstract}
Ethanolic extract of the leaves of Syzygium guineense was investigated in rats and mice for analgesic and anti-inflammatory activities. The activities of the extract was tested on the egg white induced oedema, acetic acid induced writhing and hot plate pain models. The $L D_{50}$ of the ethanolic extract of $S$. guineense was found to be $3.807 \mathrm{~g} / \mathrm{kg}$. At concentrations of $500 \mathrm{mg} / \mathrm{kg}$ and $1000 \mathrm{mg} / \mathrm{kg}$ the extract was found to possess significant $(P<0.05)$ analgesic effects on the hot plate model, but only the concentration of 1000 $\mathrm{mg} / \mathrm{kg}$ possessed significant $(P<0.05)$ anti-inflammatory and analgesic effects on the writhing test. Lower concentration of $200 \mathrm{mg} / \mathrm{kg}$ possessed insignificant $(P>0.05)$ anti-inflammatory and analgesic effects. Phytochemical test revealed that the extract contains flavonoids, tannins, cardiac glycosides and saponins. These results support some of the use of the plant in folk medicine.
\end{abstract}

Keywords-Syzygium guineense, Analgesic activity, Anti-inflammatory activity: Phytochemical constituents.

\section{INTRODUCTION}

Syzyguim guineense, Family Myrtaceae, is a medicinal plant in northern Nigeria. In northern Nigeria it is called Malmo (Hausa), while in southern Nigeria it is called Adere (Yoruba).

S. guineense is a leafy forest tree found in many parts of Africa both wild and domesticated. S. guineense is the most wide spread and abundant Syzygium in Nigeria. The flowers are often attacked by gall insects causing the inflorescence to develop into a densely- branched compact heads. The variety guineense may be distinguished by the loosely branched terminal inflorescences and rather small grayish fruits, which are not edible. Trees are up to 50 feet and 8 feet in girth. Leaves are 2.5- 6 inches long by 1-3inches, broad, elliptic tapering to a short point or sometimes, abruptly acuminate, narrowly cuneate, dark green, leathery stalk. Flowers (NovemberApril) - mostly in terminal inflorescence upright at the end of the shoots and covering the whole tree most conspicuously Fruits (April- June) - usually quite small and slightly ellipsoid, sometimes nearly spherical. Habitat- fringing forest by streams and rivers in savanna regions (Dalziel, 1937). Leaf decoctions are taken against intestinal parasites and stomach-ache, used as an enema against diarrhoea, and used as an embrocation to bathe and then massage into areas of sprain. Leaf decoctions or pulverized leaves are given as tonic to pregnant women. The leaf is chewed against stomach-ache. A liquid of chewed leaves mixed with water is used as eye drops to treat ophthalmia. The fruit is used for treating dysentery. (Burkill, H.M. 1987).

ANIMALS

\section{MATERIALS AND METHODS}

Adult albino rats of either sex (weighing 200 - 250g) and Wister albino mice of either sex (weighing 25-30g) were used for this experiment. The animals were bred and kept in cages under standard environmental conditions in the animal house of the University of Jos Nigeria. They were fed with standard animal pellets (Pfizer Feeds, Nigeria) and water ad libitum.

\section{PLANT MATERIALS}

The leaves of S.guineense were collected from Toro Local government council of Bauchi state of Nigeria by a herbalist in Jos, Plateau State, Nigeria. It was identified and authenticated by a taxonomist, Dr. A.I. Kareem of College of Forestry, Jos Plateau State.

\section{PREPARATION OF EXTRACT}

The leaves were cleaned and dried under shade and reduced to powder using mortar and pestle, and stored in air tight containers until use. The powdered plant parts were soxhlet extracted using a mixture of water and ethanol (30:70). The resultant extracts were filtered and evaporated to dryness on steam bath at a temperature of $80^{\circ} \mathrm{C}$. The dried extract was weighed; the percentage yield was determined and it was preserved in the refrigerator until use. 


\section{ACUTE TOXICITY TESTING}

The $\mathrm{LD}_{50}$ values of the extract were determined in mice following intraperitoneal administration as described by Lorke (1983).

\section{WRITHING REFLEX TEST IN MICE}

\section{TESTS FOR ANALGESIC ACTIVITY}

Mice of either sex were divided in to 5 groups of 5 each. Group 1 received normal saline (control), another group received standard drug (Aspirin $5 \mathrm{mg} / \mathrm{kg}$ ) and the other 3 groups received 3 doses of $S$. guineense extract $(200 \mathrm{mg} / \mathrm{kg}, 500$ and $1000 \mathrm{mg} / \mathrm{kg}$ ) intraperitoneally. Thirty minutes later, $0.1 \mathrm{ml}$ of $1 \%$ acetic acid was injected intraperitoneally, and the number of writhing movements was observed for 15 minutes beginning 5 minutes after injection of acetic acid. The percentage inhibition of writhing movement was then calculated.

\section{HOT PLATE TEST}

Rats were divided into 5 groups of 5 rats each, group 1 served as control and received normal saline, another group received standard drug (pentazocine $5 \mathrm{mg} / \mathrm{kg}$ ), and the other groups received 3 doses of $S$. guineense extract $(200 \mathrm{mg} / \mathrm{kg}, 500 \mathrm{mg} / \mathrm{kg}$ and $1000 \mathrm{mg} / \mathrm{kg}$ respectively). The pretreated rats were kept individually in a glass beaker on a hot plate having a constant temperature of $55 \pm 1^{\circ} \mathrm{C}$ the time taken for either paw licking or jumping were recorded.

\section{PHYTOCHEMICAL SCREENING OF THE EXTRACT}

The method described by Trease and Evans (1983) were used to chemically analyze the extract for the presence of alkaloids, saponins, tannins, glycosides, flavonoids resins and carbohydrate.

\section{ANTI-INFLAMMATORY TEST}

Animals used for this test were fasted for 12 hours and deprived of water only during the experiment. The rats were divided into 5 groups of 5 animals each. One group received normal saline, another received standard drug (Piroxicam $5 \mathrm{mg} / \mathrm{kg}$ ), while the other groups received 3 doses of the extract $(200 \mathrm{mg} / \mathrm{kg}$, 500 $\mathrm{mg} / \mathrm{kg}$ and $1000 \mathrm{mg} / \mathrm{kg}$ respectively) administered intraperitonealy, 30 minutes before the induction of inflammation. Acute inflammation was induced by injecting egg albumin into the sub- planter surface of the rat hind paw linear circumference, edema was assessed in terms of difference in zero time linear circumference at the injected paw and it circumference at 30 minutes interval after egg albumin injection.

\section{STATISTICAL ANALYSIS}

The group means \pm SEM was calculated for each analyte and reported. Significant differences between means were evaluated by one way analysis of variance (ANOVA). Post hoc test analysis was done using Dunnet test with SPSS version 16.0 package. Values of $\mathrm{P}<0.05$ were considered as statistically significant.

\section{ACUTE TOXICITY TESTING}

\section{RESULTS}

The intraperitoneal $\mathrm{LD}_{50}$ of $S$. guineense extract was found to be $3.807 \mathrm{~g} / \mathrm{kg}$

\section{ANALGESIC ACTIVITY}

The extract at a dose of $1000 \mathrm{mg} / \mathrm{kg}$ significantly $(\mathrm{P}<0.05)$ reduced the number of acetic acid induced writhings by $87.2 \%$ compared with Aspirin $5 \mathrm{mg} / \mathrm{kg}$ which caused $69.8 \%$ reduction in the number of writhings (Table 1). In hot plate test, the extract at $500 \mathrm{mg} / \mathrm{kg}$ and $1000 \mathrm{mg} / \mathrm{kg}$ significantly $(\mathrm{P}<0.05)$ increased the after treatment reaction time compared with positive control (Table 2).

\section{ANTI-INFLAMMATORY ACTIVITY}

The extract at a dose of $1000 \mathrm{mg} / \mathrm{kg}$ significantly $(\mathrm{P}<0.05)$ reduced the egg albumin induced inflammation in rats by $36 \%$ while Piroxicam $(5 \mathrm{mg} / \mathrm{kg}$ ) reduced it by $64 \%$ (Table 3 ).

\section{PHYTOCHEMICAL SCREENING}

The preliminary phytochemical screening reveals the presence of flavonoids, tannins, saponins and cardiac glycoside as shown below (Table 1) 
TABLE 1: Effect of ethanolic extract of $S$. guineense on acetic acid induced writhing test on mice

\begin{tabular}{llll}
\hline Treatment & Dose $(\mathbf{m g} / \mathbf{k g})$ & Mean & \% Inhibition \\
\hline Normal Saline & & $35.8 \pm 1.393$ & \\
EXTRACT & 200 & $5.6 \pm 1.24$ & 56.4 \\
EXTRACT & 500 & $15.4 \pm 0.678$ & 57.0 \\
EXTRACT & 1000 & $4.60 \pm 0.927 *$ & 87.2 \\
Aspirin (Standard) & 5 & $10.8 \pm 0.927$ & 69.8 \\
\hline
\end{tabular}

$*$ = Significant at $\mathrm{P}<0.05$. Significantly different compared to negative control

TABLE 2: Effect of ethanolic extract of $S$. guineense on pain reaction time in hot plate test in rats

\begin{tabular}{llllll}
\hline Treatment & Dose $(\mathbf{m g} / \mathbf{k g})$ & $\mathbf{3 0}$ & $\mathbf{6 0}$ & $\mathbf{9 0}$ & $\mathbf{1 2 0}$ \\
\hline Normal Saline & & $2.6 \pm 0.401$ & $2.7 \pm 0.34$ & $2.7 \pm 3.75$ & $2.7 \pm 0.40$ \\
EXTRACT & 200 & $3.5 \pm 0.09$ & $4.1 \pm 0.18$ & $3.5 \pm 0.17$ & $3.3 \pm 0.18$ \\
EXTRACT & 500 & $3.8 \pm 018 *$ & $5.1 \pm 0.14^{*}$ & $4.5 \pm 0.22^{*}$ & $3.3 \pm 0.30^{*}$ \\
EXTRACT & 1000 & $4.2 \pm 0.13^{*}$ & $5.6 \pm 0.10^{*}$ & $4.6 \pm 0.12^{*}$ & $3.4 \pm 0.23^{*}$ \\
PENTAZOCINE & 5 & $5.3 \pm 0.32$ & $7.9 \pm 0.26$ & $6.3 \pm 0.20$ & $4.2 \pm 0.226$ \\
\hline
\end{tabular}

$*$ = Significant at $\mathrm{P}<0.05$. Significantly different compared to negative control

TABLE 3: Effect of ethanolic extract of $S$. guineense on egg albumin induced paw oedema in rats

\begin{tabular}{llllllll}
\hline Treatment & $\begin{array}{l}\text { Dose } \\
\text { (mg/kg) }\end{array}$ & $\mathbf{1 h r}$ & $\begin{array}{l}\text { \% } \\
\text { inhibition }\end{array}$ & $\mathbf{2 h r}$ & $\begin{array}{l}\text { \% } \\
\text { inhibition }\end{array}$ & 3hr & $\begin{array}{l}\text { \% } \\
\text { inhibition }\end{array}$ \\
\hline $\begin{array}{l}\text { Normal } \\
\text { Saline }\end{array}$ & & $3.61 \pm 0.12$ & & $3.58 \pm 0.05$ & & $3.47 \pm 0.09$ & \\
EXTRACT & 200 & $3.45 \pm 0.06$ & 04 & $3.30 \pm 0.02$ & 09 & $3.14 \pm 0.04$ & 10 \\
EXTRACT & 500 & $3.29 \pm 0.07$ & 09 & $3.01 \pm 0.05$ & 16 & $2.81 \pm 0.03$ & 19 \\
EXTRACT & 1000 & $2.76 \pm 0.03 *$ & 24 & $2.53 \pm 0.05 *$ & 29 & $3.47 \pm 0.09 *$ & 36 \\
PIROXICAM & 5 & 2.20 & 39 & 1.95 & 46 & 1.26 & 64 \\
\hline
\end{tabular}

* = Significant at $\mathrm{P}<0.05$. Significantly different compared to negative control.

TABLE 4: Phytochemical Tests for Ethanolic Extract of S. guineense

\begin{tabular}{lc}
\hline TEST & S. guineense \\
\hline ALKALOIDS & - \\
CARDIAC GLYCOSIDES & ++ \\
SAPONINS & ++ \\
FLAVONOIDS & ++ \\
TANNINS & ++ \\
CARBOHYDRATES & ++ \\
\hline
\end{tabular}

KEY: + indicates presence- indicates absence

\section{DISCUSSION}

The intraperitoneal $\mathrm{LD}_{50} S$. guineense was found to be $3.807 \mathrm{~g} / \mathrm{kg}$. Scientifically plants are assayed for $\mathrm{LD}_{50}$ values to establish their safety. The result for this study showed that the intraperitoneal $\mathrm{LD}_{50}$ are within safety margins. This suggests that the extract is safe for consumption.

The extract inhibits the acetic acid induced writhing reflex on mice at higher doses. Plants that are effective in this test have peripheral analgesic activity (Otimenyin et al., 2004). The result suggests that these plants can be useful for peripherally induced pain. Acetic acid induced writhing test have been associated with increase in the level of prostaglandins in peritoneal fluid (Leveni et al, 1984), so the mechanism of activity of the extract may be linked to cyclooxygenases.

The result of the hot plate test showed that $S$. guineense extract significantly increased the pain reaction time of the rats on hot plate. According to Turner (1965) hot plate test is a model for assaying effects of drugs on central pain. Drugs that are effective in this model have central analgesic effect. 
The extracts of the plant under investigation showed significant anti-inflammatory activity on the fresh egg-albumin induced inflammation as against the progressive increase in the rat paw circumference in the control. They suppressed the increase in rat paw oedema in a dose dependent manner two or three hours after the injection of inflammatory agent. This implies that the extracts will be useful in the management of inflammatory pain (Wannang et al., 2007). Pain and inflammation are complementary and always occur together.

\section{PHYTOCHEMICAL STUDIES}

Phytochemical screening of the plant revealed that $S$. guineense extract contain flavonoids, tannins, saponins and carbohydrate. Alkaloids and cardiac glycosides are also present. These phytochemical constituents are physiologically active compounds possessing great potential for therapeutic and prophylactic uses. Analgesic and anti-inflammatory effects of flavonoids and tannins have been reported (Das et al., 1989). These might be responsible for the analgesic activities of the plant extract seen in this study. Flavonoids are also known for their antiallergic, antimicrobial and anti cancer properties (Yumi and Richard, 2001).

The above result therefore supports their use by traditional healers for various forms of pains and inflammatory conditions such as arthrithis and rheumatism.

\section{REFERENCES}

[1]. Burkill, H.M., 1997. The useful plants of West Tropical Africa. 2nd Edition. Volume 4, Families M-R. Royal Botanic Gardens, Kew, Richmond, United Kingdom. 969 pp.

[2]. Dalziel, J.M. 1937. The useful plants of west Tropical Africa Crown Agents for the Colonies London. pp 334-335

[3]. Das, P. C. Das, A. and Mandals S. (1989). Antimicrobial and Anti inflammatory activities of the Seed Kernel of Mangifera indica. Fitotherapy. 60, 235-240

[4]. Ior, L. D. Uguru, M. O. Olotu, P. N. Ohemu T. L. and Ukpe, A.(2011). Evaluation of Analgesic and Anti-inflammatory Activities and Phytochemical Screening of the leaves extract of Paullinia pinnata (Sapindaceae), Journal of Chemical and Pharmaceutical Research. J. Chem. Pharm. Res., 2011, 3(4): 351-356

[5]. Levini, J.D. Lau, W.K. Kwait, G. and Goetzl, E.J. (1984). Leukotriene B4 Produces Hyperalgesia that is Dependent on the Polymorph-Nuclear Leucocytes. Science 225,743-745

[6]. Lorke D (1983) A new approach to practical acute toxicity testing.. Arch Toxicology.54(4):275- 287.

[7]. Otimenyin, S. O. Uguru, M. O.Auta. A. (2008) Anti inflammatory and Analgesic Activities of Cassia goratensis and Sacrocephalesus esculentus Extracts. Journal of Herbs, spices \& Medicinal plants , vol. 13, no. 2, pp. 59-67,

[8]. Trease G.E and Evans W.C (1983). Pharmacocnosy. Baillere Tindall, London, 12 $2^{\text {th }}$ ed, pp. 387, 457-476

[9]. Turner, R.A. (1965). Screening Methods in Pharmacology. Academic Press, New York pg. 106

[10]. Wannang, N.N, Anuka, J.A, Kwanashie, H.O and Auta, A. (2006). Analgesic and anti inflammatory activity of the Aqueous Leaf Extract of Solanum nigrum Linn (Solanaceae) in Rats, Nigerian Journal of Pharmaceutical Research, Vol 5 No.1, pp 9-13

[11]. Yumi, Y. and Richard, B.G. (2001). Therapeutic Potential of Inhibition of the nf-kb pathway in the treatment of Inflammation and Cancer. Journal of Clinical investigation 107(2): 135 - 142 